\title{
Sobre o claro enigma de Trouxa frouxa ${ }^{1}$
}

Fábio Dobashi Furuzato

\author{
Não amei bastante sequer a mim mesmo, \\ contudo próximo. Não amei ninguém. \\ Salvo aquele pássaro - vinha azul e doido- \\ que se esfacelou na asa do avião. \\ Carlos Drummond de Andrade
}

Examinar uma bagagem é, em certa medida, conhecer o viajante e a natureza de seu percurso: este, um homem de negócios; aquele, um turista; o outro, um contrabandista; e assim por diante. O jogo pode ser fácil, quando se trata de identificar estereótipos, mas torna-se cada vez mais interessante, na medida em que nos distanciamos dos tipos óbvios e nos aproximamos de figuras humanas complexas. No caso de Trouxa frouxa- o quarto livro de ficção de Vilma Arêas -, ao examinarmos cuidadosamente cada uma das trinta e três peças que o compõem, é que nos vamos dando conta do tipo de obra que temos em mãos - a bagagem - e da concepção artística de sua autora - a viajante em seu percurso.

Já se disse, a respeito da obra de Vilma, que ela se aproxima das de Dalton Trevisan, Rodrigo Naves, Modesto Carone e também da poesia do italiano Eugenio Montale. Os motivos dessas aproximações seriam, basicamente, sua prosa minimalista, ao mesmo tempo coloquial e poética, pela tensão significativa da linguagem; sua forte e constante preocupação com a realidade social; e o uso de inúmeras referências não explícitas, que fazem com que os pequenos textos nunca revelem seu sentido por completo, convidando-nos à releitura, à experiência e à reflexão.

De fato, em meio à grande variedade formal e temática dos textos de Trouxa frouxa, essas características se destacam, conferindo harmonia aos elementos do conjunto. Os pequenos textos são às vezes descrições de cenas, situações, paisagens, como nos casos de "Furo na mácula" e alguns dos "Cromos" e "Praias" - dos mais belos de todos. Outras vezes são narrativas curtas, como o divertidíssimo "Boquinha" - cujo riso é suspenso pelo lirismo inesperado do final -, "Algaravia" e a trama sofisticada de "Ema". Há ainda pequenos poemas - "Rol" e algumas "Cartinhas" - e epigramas - "Sonho" e o terceiro "Dudu". E cada um desses textos exige do leitor uma atitude específica, uma chave diferente.

No conto "Pássaro.doc", por exemplo, em meio aos devaneios da personagem principal, que parece recordar o enterro de algum parente próximo, surge, como um enigma, aquele pássaro azul e doido do poema acima, de Drummond.

E a história é narrada de tal forma que o leitor fica sem saber quem é essa personagem principal, pois não se diz nem se se trata de um homem ou uma mulher, nem se explicita a sua relação com o episódio do enterro. É como se o narrador nos colocasse 
diretamente em contato com a consciência da personagem, sem maiores explicações. Os fatos surgem então como fragmentos, misturados às idéias e impressões.

Aqui e ali, ecoam versos de Drummond, adquirindo novas significações: Do que restou, como compor um homem?; Vinha azul e doido e se esfacelou contra a asa do avião. Do mesmo modo, o conto de Vilma ganha um novo significado ao relermos a "Confissão" do grande poeta de Itabira: Não amei bastante meu semelhante,/ não catei o verme nem curei a sarna./ Só proferi algumas palavras,/ melodiosas, tarde, ao voltar da festa.

Em "Pássaro.doc", o pai e a tia discutem durante o enterro: Sofriam. E, no final, há o choque com outra realidade mais ampla que a dor familiar: De repente começaram a brotar crianças esfarrapadas de trás dos túmulos. Imploravam moedas. Qualquer moedinha servia, iam ajuntar e depois tomar café com pão na esquina, pois estavam com fome.

À surpresa poética da imagem das crianças esfarrapadas que começam a brotar, de trás dos túmulos, contrapõe-se a crueza da realidade que tanto conhecemos: estavam com fome.

Assim, a insuficiência do amor humano, dolorosamente admitida em "Confissão", encontra ressonância neste conto de Vilma e em outros episódios de Trouxa frouxa. Dois desses episódios levam justamente o nome de "Amor". No primeiro deles, o leitor se vê na intimidade de um casal que se reencontra. Aos poucos, o narrador vai nos fornecendo informações esparsas sobre o encontro: Você está esquisito, cortou o cabelo, ela disse. Cortei, ele disse, quanto tempo passou?; e sobre o ambiente em que ele se dá: Na sala fumavam crack num cachimbo branco como de brinquedo, e jogavam cartas.

Mas, ao contrário do que ocorre segundo a visão mais corrente relacionada com o uso de drogas como o crack, não há nenhuma associação disso com a idéia de criminalidade ou violência. Toda a situação, aliás, é descrita como um fato cotidiano, com simplicidade e uma elegante economia na linguagem.

Ela adormeceu vendo estrelas negras sobre cactos batidos de areia. O vazio da ausência de $\operatorname{luq}$.

O segundo "Amor" nos coloca diante da incompreensão: Bêbado, o príncipe ataca a bela pela janela do carro, esmaga a cabeça - que importa o pescoşo torto? - no abraço contra o peito.

O que se apresenta aqui são sentimentos opostos de dois seres vivendo uma mesma situação, de certa forma, "amorosa":

- Detesto mulher burra que não compreende a alegria de um homem.

Ela tem nojo do beijo encharcado e do suor do corpo.

O amor em Trouxa frouxa nos remete então a "Amar", outro célebre poema de Claro enigma: Que pode uma criatura senão,/ entre criaturas, amar?/ amar e esquecer,/ amar e malamar,/ amar, desamar, amar?/ sempre, e até de olhos vidrados, amar?.

Não se trata aqui de comparar o trabalho de Vilma Arêas à poesia de Drummond, mas apenas de apontar aspectos na modernidade da autora que encontram correspondência na grande literatura brasileira do século XX: a consciência sobre a insuficiência do amor humano e sobre os limites da compreensão que temos da realidade. Não é à toa que a visão de mundo que se apresenta em Trouxa frouxa é sempre fragmentada.

Também não se trata de querer propor uma única chave que abra todos os textos deste livro de Vilma, revelando por completo seus enigmas. Como já se disse, cada um 
Remate de Males - 26(2) - jul./dez. 2006

dos textos exige uma atitude diferente por parte do leitor. Em alguns casos, podemos até nos questionar se de fato os enigmas têm respostas e se de fato eles nos perguntam: Trouxeste a chave?

É preciso lê-los.

\section{Nota}

1 Resenha publicada originalmente em Scripta. Revista do Programa de Pós-graduação em Letras e do CESPUC. Belo Horizonte v. 4, n. 8. $1^{\circ}$ semestre de 2001, pp.423-425. 